\title{
Jesus, Josephus, and the fall of Jerusalem: On doing history with Scripture
}

\begin{tabular}{|c|c|}
\hline $\begin{array}{l}\text { Author: } \\
\text { William den } \mathrm{H}\end{array}$ & ollander ${ }^{1,2,3}$ \\
\hline $\begin{array}{l}\text { Affiliations: } \\
{ }^{1} \text { Theologische } \\
\text { Kampen, The }\end{array}$ & $\begin{array}{l}\text { Universiteit } \\
\text { Netherlands }\end{array}$ \\
\hline $\begin{array}{l}{ }^{2} \text { Department } \\
\text { Testament Stu } \\
\text { of Theology, } \\
\text { Pretoria, Sout }\end{array}$ & $\begin{array}{l}\text { ff New } \\
\text { dies, Faculty } \\
\text { Iniversity of } \\
\text { h Africa }\end{array}$ \\
\hline $\begin{array}{l}{ }^{3} \text { Canadian Ref } \\
\text { Theological Se } \\
\text { Hamilton, Can }\end{array}$ & $\begin{array}{l}\text { ormed } \\
\text { minary, } \\
\text { lada }\end{array}$ \\
\hline $\begin{array}{l}\text { Note: } \\
\text { Dr William de } \\
\text { a research ass } \\
\text { project 'Biblic } \\
\text { Hermeneutics } \\
\text { Prof. Dr Andri } \\
\text { professor eme } \\
\text { senior fellow i } \\
\text { Advancement } \\
\text { at the Faculty } \\
\text { of the Univers } \\
\text { South Africa. }\end{array}$ & $\begin{array}{l}\text { Hollander is } \\
\text { ociate in the } \\
\text { al Theology and } \\
\text {, directed by } \\
\text { es G. van Aarde, } \\
\text { ritus and } \\
n \text { the Unit for } \\
\text { of Scholarship } \\
\text { of Theology } \\
\text { ity of Pretoria, }\end{array}$ \\
\hline $\begin{array}{l}\text { Corresponder } \\
\text { William den } \mathrm{H}\end{array}$ & $\begin{array}{l}\text { ce to: } \\
\text { ollander }\end{array}$ \\
\hline $\begin{array}{l}\text { Email: } \\
\text { wdenhollande }\end{array}$ & r@crts.ca \\
\hline $\begin{array}{l}\text { Postal addres } \\
251 \text { West } 15 \text { th } \\
\text { ON, L9C 4B6, }\end{array}$ & $\begin{array}{l}\text { s: } \\
\text { St. Hamilton, } \\
\text { Canada }\end{array}$ \\
\hline $\begin{array}{l}\text { Dates: } \\
\text { Received: } 19 \\
\text { Accepted: } 10 \\
\text { Published: } 14\end{array}$ & $\begin{array}{l}\text { Mar. } 2015 \\
\text { May } 2015 \\
\text { Aug. } 2015\end{array}$ \\
\hline $\begin{array}{l}\text { How to cite th } \\
\text { Den Hollande } \\
\text { 'Jesus, Joseph } \\
\text { fall of Jerusale } \\
\text { history with S } \\
\text { HTS Teologies } \\
\text { Theological St } \\
\text { Art. \#2942, } 9 \\
\text { dx.doi.org/10 } \\
\text { v71i1.2942 }\end{array}$ & $\begin{array}{l}\text { is article: } \\
\text { W., 2015, } \\
\text { us, and the } \\
\text { m: On doing } \\
\text { cripture', } \\
\text { e Studies/ } \\
\text { udies } 71(1) \text {, } \\
\text { oages. http:// } \\
4102 / \text { hts. }\end{array}$ \\
\hline Read online: & \\
\hline 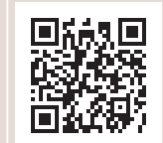 & $\begin{array}{l}\text { Scan this QR } \\
\text { code with your } \\
\text { smart phone or } \\
\text { mobile device } \\
\text { to read online. }\end{array}$ \\
\hline
\end{tabular}

The destruction of the temple in Jerusalem by the Romans in AD 70 was an unquestionably traumatic event in the history of the Jewish people. By all accounts it was a social, political, and theological disaster. As such, contemporary Jewish figures wrestled with the meaning of the event. This article analyses the efforts by two figures in this internal Jewish dialogue to provide this meaning, namely, the historian Josephus and Jesus of Nazareth. We will see that in both cases the meaning of the destruction was rooted in the firm conviction of the God of Israel's existence and his self-revelation in Scripture. The temple was destroyed not apart from God or in spite of God, but in full accordance with his will. This will, moreover, was judged to be accessible through Scripture, both in terms of its prophetic value and its establishment of a metanarrative - redemptive history - that provided a framework for historical events. In addition, the reason for the destruction was judged by both to be the sins of (certain) people. The major difference between them lay rather in the question of which sins exactly were judged to be responsible.

\section{Introduction}

According to Windisch (1914):

It was not just that a people, lately flourishing, had been trampled underfoot. What was at issue was faith itself in the power, faithfulness, and goodness of God. Over the smoking ruins of Jerusalem the nagging and torturing question posed itself, the question of God. It seemed more hopeless than ever to expect an answer. (p. 19)

Thus Windisch evocatively described the impact of the destruction of Jerusalem and the temple, certainly capturing the emotional upheaval it caused the Jews of the 1st century and beyond. But was the prospect of an answer to the question posed by the tragedy really so bleak? Perhaps not, for the Jews had the resources to deal with such a traumatic event. In the first place, they uniformly shared the conviction that God existed and that whatever happened was in accordance with his purpose and will. ${ }^{1}$ In the second place, as these unshakeable beliefs were rooted in divine revelation, God's purpose and will could also be discerned. With these two principles the purposeful nature of God's actions in human history and his communication of his will - the Jews of the 1st century were adequately prepared to wrestle with the difficult questions evoked by the rubble of the holy city in AD 70 and, indeed, to expect answers.

The aim of the present article, then, is to consider the efforts of two 1st century Jews, Josephus and Jesus of Nazareth, to provide meaning for the destruction of the temple within the context of such firmly held convictions. While contemporary scholars distinguish between the historical and the moral or theological explanations for the revolt, ${ }^{2}$ such a division did not occur to these ancient observers. For them, as for their compatriots, past, present, and future were inextricably linked, not because they were associated by a series of material causes that could be rationally apprehended and empirically tested, but because together they formed a metanarrative - a Heilsgeschichte or redemptive-history, broadly conceived - in which the God of Israel was working towards a defined telos, the restoration of the broken relationship between himself and his specially-chosen people.

As such, the fundamental cause of the fall of Jerusalem and destruction of the temple was not, according to Josephus, a certain political or social feature of 1st century Judaea, even if he does

\footnotetext{
1.Price (2007:181): "Jews of the Destruction generation - at least so far as we know - did not question the existence of God; the farthest they would go was to question His presence and the nature of His presence and of His justice as the Temple burned. That the Temple was burned in accordance with His will was never questioned.'

2.Klawans (2012:188): 'As the narrative progresses, we learn that civil strife for Josephus is not a historical cause of the Jewish defeat but a moral one'; see also Price (2005:109-120).
} 
describe various factors that contributed to the outbreak of the war. ${ }^{3}$ For the Jewish historian the ultimate cause was God himself who had decreed his temple's destruction as punishment for and purification of the sins of his people. ${ }^{4}$ In this Josephus is in full agreement with Jesus of Nazareth whose predictions offer little in the way of political or social analysis but do speak to the moral or spiritual cause. ${ }^{5}$ This agreement, we will see, is rooted in a common worldview, not only in the conviction that the God of Israel guided and intervened directly in world events, but also in accepting Scripture as the lens through which reality was to be perceived and interpreted. The present study will, therefore, examine the explanations offered by both Josephus and Jesus, which are juxtaposed as examples of an internal Jewish dialogue about the traumatic events of AD 70, ${ }^{6}$ highlighting the similarities and noting the differences where appropriate.

\section{Josephus on the fall of Jerusalem Scriptural worldview}

That the God of Israel was involved in the course of human history was an unquestioned assumption for Josephus, one that would not have raised many eyebrows amongst the members of his audience in the city of Rome. While they might not necessarily view the involvement of the gods as subject material for the historian, taking a more Thucydidean view of things, ${ }^{7}$ the typical Greek or Roman audience member or reader would nonetheless understand, if not accept, the judgement that certain aspects of the Jewish war against Rome could be explained only by divine involvement. The Flavian emperors themselves publicly claimed that their victory over the Jews could be attributed to divine favour. ${ }^{8}$ Thus, unsurprising in their ancient context are those moments in the narrative where Josephus credits certain events or outcomes to the transempirical. ${ }^{9}$ For example, at the critical

3.The scholarly literature on the causes of the First Jewish Revolt is extensive; see, for example, Bilde (1979:179-202); Goodman $(1987,2007)$.

4.Contra McLaren (1998:16): 'The dependency on Josephus appears to be quite promising in comparison to the dependency on Acts for the early Christian movement, and to the Gospel narratives for Jesus of Nazareth. Concern over possible theological motivation is not an issue in Josephus's narrative. He actually sought to write a history; his stated aim was to preserve an account of actual events (emphasis added). We will see below that the similarities between Josephus's presentation and that of Jesus in the gospels are striking.

5.As Borg observes: 'This also means that the threats were not issued simply out of a perception that Israel's present course would lead to a collision with Rome (which would make Jesus primarily a political analyst, at least at this point) but out of a conviction that Israel's present course did not conform to Yahweh's intent for the people of God' (1998:210)

6.I disagree, therefore, with the decision of Price to omit consideration of the New Testament traditions in his analysis of reactions to the consideration of the New because, 'in [Price's] opinion, the Christians' search for the meaning of the destruction, and their standard answer, having to do with Jesus' prophecy, has no destruction, and their standard answer, having to do with Jesus' prop
direct importance to the internal Jewish dialogue' (2007:184, n. 4).

7.See, for example, Thucydides 1.22 .4 , although his actual historiography is in fact more open to the possibility of divine direction. That Josephus himself viewed Thucydides highly and was influenced by him is evident from his narratives (see esp. Ap. 1.18) and has been amply demonstrated in contemporary scholarship; see especially Feldman (1998:140-148); Mader (2000); Rajak (2002:91-94).

8.See Suetonius, Vesp. 5.6; Cassius Dio 65.1.3; Silius Italicus, Pun. 3.570-629; cf Goodman (1987:237). The Flavian coinage also emphasised the gifting of peace by the gods (see e. RIC 2.50 no. 296, 303. 52 no. 316. 53 no. 323, 326, 327; 54 no. $338 ; 55$ no. $343 ; 57$ no. 356 ), and the Templum Pacis made it very clear that the $338 ; 55$ no. $343 ; 57$ no. 356$)$, and
Roman gods were to be thanked.

9.The use of the term 'transempirical' to refer to that which cannot be tested or The use of the term 'transempirical' to refer to that which cannot be tested or
demonstrated by traditional empirical methods is drawn from Thiselton (2007:377), who speaks of 'transempirical realities'; cf. Deines (2013:1-28). moment of the Roman assault on the Temple Mount, it is

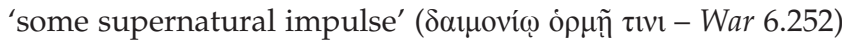
that motivates a certain soldier to hurl his flaming torch into the sanctuary. Elsewhere in his account, Josephus credits

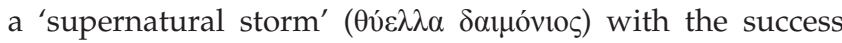
of the Romans in their siege of Gamala (War 4.76), while at Masada the turning point is a wind that changes direction

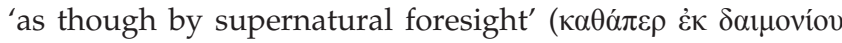
זpovoías - War 7.318). ${ }^{10}$

We should not think, however, that the theological undercurrent in Josephus's account of the Jewish war was on this account simply reflective of a general belief in the existence and activity of the spirit world or of Josephus's close relationship with the Roman emperors, whose claim to divine favour he hereby parroted. ${ }^{11}$ For when we dig further into what Josephus considered the God of Israel was doing in the war, it becomes clear that Josephus's view is far from generic and far from Roman. Rather, God's involvement in the war as described by Josephus can only be understood through the lens of Scripture, as that was also the Jewish historian's sightline when seeking to explain the events he himself had observed and in which he had taken part. ${ }^{12}$

This is above all evident in the conviction that the Jewish people were the chosen ones who had a special relationship with their God that could not be broken by any defeat at the hands of a foreign world power. Josephus does, famously, state that 'God, who went the round of nations, bringing to each in turn the rod of empire, now rested over Italy' (War 5.367). ${ }^{13}$ While this picture of God changing his residence from Jerusalem to Rome fits in well with the Roman siege practice of evocatio deorum, whereby they called out the gods of conquered nations to join them prior to destroying the city (Nodet 2007:103), Josephus's narrative as a whole prevents us from casting this statement in an entirely Roman light. ${ }^{14}$ Instead, God's abandonment of his sanctuary and his support of the Romans in their suppression of the revolt are situated within the sin-punishment/obedience-reward paradigm that governed Josephus's interpretation of life for the chosen people of God.

This framework was inspired by principles that were established in the Jewish Scriptures, in particular the book of

10.For other examples of such references to the 'supernatural' or 'other-worldly', see also War $1.331 ; 3.341,485 ; 4.34,501,622 ; 5.377 ; 6.297,303 ; 7.82 ;$ cf. Mason
$(2008: 335-336$ n. 2805). These passages, together with those above, deserve further attention.

11.See Goodman's observation regarding previous scholarship, 'It has also long been remarked that Josephus extolled the Roman state throughout his writings. God was on the Roman side (War 5.367-368, 412), hence they held the whole world in thrall (5.366) ... Thus, in identifying with the victor, Josephus could claim that he was being a good Jew' (1994:335-336). For a description of the traditional view of Josephus's as Flavian lackey and propagandist, along with references to the relevant scholarly books and articles, see Den Hollander (2014:8-11).

12.For a valuable recent article arguing for the influence of Jeremiah 7 in particular on Josephus's portrayal of the war, see Ferda (2013:158-173).

13.See also War 5.371; 412, 'My belief, therefore, is that God has fled from the holy places and taken his stand on the side of those with whom you are now at war.'

14.Contra Kloppenborg (2005:419-450, esp. 442-444), although he does end by observing, 'according to Josephus, the deity's departure was due instead to the
impious conduct of the "tyrants" who had seized control of the city and temple who were responsible for the catastrophe of the First Revolt.' 
Deuteronomy, which was of central importance in the Second Temple period, as the large number of copies amongst the Dead Sea Scrolls clearly attests. ${ }^{15}$ The framework is most explicitly laid out in Moses' speech describing the blessings and curses of the covenant. ${ }^{16}$ In his rendition of this speech in his Jewish Antiquities, Josephus himself echoes the scriptural message that covenant obedience would be rewarded and disobedience harshly punished (Ant. 4.189-191, 312-314), although he does tailor the message to reflect more exactly the destructions of $586 \mathrm{BC}$ and $\mathrm{AD} 70 .{ }^{17}$ In fact, he identifies this as the key message of Antiquities:

$[O]$ ne who would wish to read through it would especially learn from this history that those who comply with the will of God and do not venture to transgress laws that have been wellenacted succeed in all things beyond belief and that happiness lies before them as a reward from God. But to the extent that they dissociate themselves from the scrupulous observance of these laws the practicable things become impracticable, and whatever seemingly good thing they pursue with zeal turns into irremediable misfortunes. (Ant. 1.14; cf. 1.20, 23, 72; 6.307; 7.93; $17.60 ; 19: 16)$

That Josephus had this principle in mind also when he was composing Jewish War is clear from his description of the disasters that befall individuals such as Aristobulus, Herod, Simon bar Giora, John of Gischala, and the Roman governor Catullus as direct consequence of their wicked actions. ${ }^{18}$ The causal link he makes between their actions and their just deserts is grounded in the principle that God punishes sins.

Josephus also locates his explanation for the destruction of the temple within this framework. As Klawans has observed, 'simply put, Jerusalem fell for its sins (War 6.95-102; cf. Ant. 20.166)' (2010:290). Precisely which sins these were is not laid out consistently in War, but we should not expect Josephus to have a fully worked out theological explanation (Price 2005:117-119). He was wrestling with the catastrophe that had overcome his people. Throughout the narrative, however, there is the clear message that certain actions brought about the displeasure of God and led to the punishment of his people at the hands of the Romans. These actions included especially the murder of innocents (War $4.314-325$, 334-344; 5.15-18; 6.200-213), the desecration of the temple by bloodshed (War 4.150-151, 201, 215; 5.15-18, $100-105 ; 6.95-110)$, and the violation of the Sabbath and festivals (War 2.456; 4.102-103, 402; 5.100-105), all of which contributed to the heaping up of sins that could only result 15.See Lim (2007:6-26); cf. Lincicum (2013), especially chapter 7 on Deuteronomy in
Josephus's writings.

16.See especially Deuteronomy 4, 8, 28 (chs. 4 and 28 being Moses' final discourses to the people of Israel); cf. Halpern-Amaru (1981:201-229); Ferda (2013:162)

17. Halpern-Amaru (1981:220-221). Josephus also does not use the scriptural terminology of 'covenant', although the concept does lie behind his narratives. It is simply recast in terms more familiar to his audience; see Spilsbury (1998:172-191). Sanders argues more generally that the Jews of the Second Temple period saw Sanders argues more generally that the Jews of the Second
their relationship with God in covenant terms (1977:426-428).

18.War $1.84,656 ; 6.433-434 ; 7.453$. See, similarly, the judgement regarding the death of Agrippa I in Acts 12:23, "Immediately, because Herod did not give praise to God, an angel of the Lord struck him down, and he was eaten by worms and died.' in God's abandonment of his sanctuary and the punishment of his people. ${ }^{19}$

While the concept of pollution was also familiar to Josephus's non-Jewish readers or audience members (Mason 2008:335, n. 2804), the context within which the punishment is set reveals that Josephus is nonetheless dealing with a uniquely scriptural framework. For the purpose was ultimately not retribution but correction. There was a special relationship between God and Israel that precluded the complete abandonment of his people, as Antiquities in particular makes clear (Spilsbury 1998:182-190). Thus, for example, Josephus has Moses declare to the Israelites following their rebellion at the borders of Canaan, 'For this reason He would not destroy all, nor would $\mathrm{He}$ annihilate their race, which $\mathrm{He}$ held in greater honor than all the rest of humankind' (Ant. 3.313). ${ }^{20}$ Implicit in his account of the war is, therefore, the expectation that God would return to his chosen people and, even, that his sanctuary would be restored..$^{21}$ This is one of the implications of Josephus's close linking of the second destruction with the first, even to the date (War 6.250, 268-269). The proscribed time of punishment and the rebuilding of the temple then fuelled the hopes and expectations that now God's displeasure was also temporary.22 For the covenant remained, even during times of punishment, and repentance would lead to a restored relationship, as the prophets made abundantly clear. ${ }^{23}$ In his account of Moses' speech, therefore, Josephus adds that, after their suffering, 'the God who created you will give back to your citizens both your cities and your Temple, the loss of these will occur not once, but often' (Ant. 4.314)..$^{24}$

Thus, far from suggesting that God's presence on the side of the Romans supported their own self-image as uniquely favoured by the gods, Josephus denied the Romans - and the Flavians in particular - ultimate credit for the victory and subordinated them to God's purposes for his own people. Moreover, while confirming the special status of his own people, he hinted at the temporary nature of the Romans' own empire (Ant. 4.115-116; 10.209-210). For the corollary was that eventually God would no longer be on the side of the Romans and the rod of rule would pass again to another

19.Ferda (2013:162-163, n. 16), provides a list of passages where Josephus describes the offences of the rebels and the resulting punishment in terms of the Deuteronomic transgressions and curses; see also Tuval (2013:110-114).

20.This is Josephus's own addition to Numbers 14:20; see Feldman (1999:ad loc., $\mathrm{n}$. 948).

21.Contra Tuval (2013:188), who writes that War was 'totally devoid of any eschatological program and did not offer any coherent scenario concerning God's future place in the history of His erstwhile chosen people Israel'.

22.See Deines (2013:210-213); cf. Goodman (2007:447-449). The Romans themselves may also have assumed that the temple would be rebuilt; see Rives (2005:145-66). Josephus himself may have been advocating in his narratives for the Romans to allow such a rebuilding through his portrayal of such figures as Alexander the Great and Cyrus of Persia; see Ant. 11.10-15, 92, 100, 317-339; cf. the description of the Second Temple treasures, War 7.148-150, 161-162, which could well have been restored to service.

23.This message is more muted in Josephus's own narrative than in the scriptura writings themselves for reasons that remain to be explored, but it is still recognisable; see Halpern-Amaru (1981:224).

24.This is in apparent contradiction with Josephus's statement immediately prior that 'they would repent to no avail' (Ant. 3.313). 
nation..$^{25}$ The Jewish nation, on the other hand, despite her present situation, was the stone of Daniel's prophecy that would destroy the kingdom of iron (Rome) and fill the whole earth (Ant. 10.210; Dn 2:31-45; cf. Spilsbury 2003:19-20; Spilsbury \& Begg 2005:265-267).

For Josephus, then, the nagging question of God was to be answered by viewing the destruction of the temple within the framework of salvation history presented in the Jewish Scriptures. The catastrophe that had befallen the Jewish nation could only be understood as a further outworking of the sin-punishment paradigm that was laid out in the book of Deuteronomy and applied to the history of Israel by the prophets. This scriptural worldview allowed Josephus to maintain the conviction that the Jewish people were special to the God of Israel and that their present lot was provisional.

\section{Scriptural exegesis}

For Josephus, however, Scripture provided not only a framework for the unfolding of history but also a rich resource of prophetic pronouncements that underlined the appropriateness of viewing the destruction as part of a Heilsgeschichte. At the heart of this second use of Scripture lay Josephus's characterisation of himself as a sort of prophet, ${ }^{26}$ a latter-day Jeremiah, ${ }^{27}$ and his work as a natural continuation of the work of the prophets in composing history..$^{28}$ Nevertheless, his own 'prophecy' and those of his contemporaries differed significantly from the biblical prophets, who spoke directly with God (Price 2007:191). Josephus never claims to have had this privilege himself. ${ }^{29}$ Instead, the prophetic pronouncements regarding the events of $\mathrm{AD} 70$ were made on the basis of a certain understanding of Scripture, namely that it had the power to speak directly to contemporary events. That is, beyond their contribution to the development of the worldview described above, the prophecies in Scripture were also able to be interpreted in such a way that they could be applied to the present and near future. ${ }^{30}$

Thus Josephus encourages his readers to pick up the book of Daniel 'to learn about the hidden things that are to come' (Ant. 10.210), and later claims that Daniel predicted not only the

25.That Josephus anticipated the end of the Roman Empire but, understandably, only hinted at this eventuality in his narratives, has been demonstrated by Spilsbury (2003:1-24, esp. 15-21); cf. Halpern-Amaru (1981:225); Bilde (1988:187-188); Gray (1993:39); Mason (1994:93-94, 172-173); Spilsbury (2002:306-327); Mason (2003:71-72, 121).

26. Most obviously through his prediction of the accession of Vespasian and Titus to the imperial throne: War 3.399-408; cf. Suetonius, Vesp. 5.6; Cassius Dio 65.1.4 Regarding the possible historicity of this prediction and its effect on Josephus's relationship with the Flavians, see Den Hollander (2014:91-104).

27.See especially War 5.391-393. The amount of scholarly literature examining this connection is considerable; see, for example, Daube (1980:26-27); Cohen (1982:366-381); Bilde (1988:55-56); Gray (1993:72-74); Gnuse (1996:27-29); Ferda (2013:158-173; Den Hollander (2014:75, 103, 144, 166-167).

28.See War 1.18: 'Where the writers of these affairs and our prophets leave off, from there I will make a beginning of my orderly account'; cf. Ap. 1.37, 41. See also Gnuse (1996:23); Feldman (1998:650).

29. He does claim to have received dreams, including in connection with his famous prediction; see War 3.351-354. We do not have space to consider these here, but see the full treatment in Gnuse (1996:esp. 135-142).

30.Thus Deines (2013:304): 'The texts which later formed the Tanakh were not preserved primarily to report a past history or revelation, but to mediate this past revelation into a means of encountering God in the future.' events that occurred under Antiochus IV Epiphanes, but also those of Josephus's own day (Ant. 10.276). He also presents the prophets Jeremiah and Ezekiel as having foreseen the destruction of the temple in AD 70.31 Exactly where Josephus thought Jeremiah's prophecy had the events of the 1st century AD in view is unclear, ${ }^{32}$ but what is apparent is that Josephus expected Scripture to speak to contemporary events. Underlying this expectation was, of course, a certain confidence that the destruction did not fall outside the control or plan of the God of Israel. In the aftermath of the war, therefore, connecting the earlier destruction with the tragedy of AD 70 must have provided a level of comfort and reassurance, as well as a further answer to the nagging question of God. ${ }^{33}$

We should not necessarily limit this phenomenon of 'charismatic exegesis' (Aune 1983:133; Gaston 1970:440-443) to the post-eventum reality when Josephus sat down to compose his account of the revolt. ${ }^{34}$ For Josephus presents the phenomenon as widespread already prior to the revolt, not only by figures such as himself, priests who, he asserted, knew the Scriptures especially well, ${ }^{35}$ but also others, such as the Essenes. ${ }^{36}$ The common people could of course, in Josephus's enlightened estimation, be seriously mislead by wrongly interpreted prophecy, such as those who gathered together at the time of Herod's capture of the city in $37 \mathrm{BC}$, and 'indulged in transports of frenzy and fabricated numerous oracular utterances to fit the crisis' (War 1.347). ${ }^{37}$

Thus, also the destruction was said to have been portended not only by signs and wonders in the heavens (War 2.650; 6.288-300; Tacitus, Ann. 5.13), but also by the circulation of existing prophecies that were applied to events of the near future. Josephus reports that, 'there was a certain ancient oracle of those men, that the city should then be taken and the sanctuary burnt, by right of war, when a sedition should invade the Jews, and their own right hand should pollute the

31.Ant. 10.79, "[jeremiah] proclaimed in advance the terrible things that awaited the city; he also left behind writings about its capture in our own time and the destruction of Babylon. Nor did he alone foretell these things to the mob; there was also the prophet Ezekiel, who left behind two books that he was the first to write about these matters'; cf. Ant. 10.79, 106-107, 141. Regarding the two books of Ezekiel, see Spilsbury and Begg (2005:ad loc. n. 341); cf. Marcus (1937:ad loc.).

32.Marcus (1937:ad loc. n. b and c), suggests the reference is to the book of Lamentations, since Josephus had just spoken of Jeremiah's lament composed in the days of Josiah; cf. Moffitt (2006:303).

33.See War 6.310, 'Reflecting on all these things one will find that God has a care for men, and by all kinds of premonitory signs shows his people the way of salvation, while they owe their destruction to folly and calamities of their own choosing.'

34.Tuval (2013:116-128) is sceptical of the extent of Josephus's knowledge of Scripture even at the time of his writing the War in Rome. This serves as part of his broader thesis that Josephus's religious profile changed from the War to the Antiquities.

35.See War 3.352; cf. 2.417; Ant. 4.304, 324; 12.49; Life 1-9, 198; Ap. 1.29-36, 54; 2.185-187; on the connection between the priests and the sacred writings, see Mason (1988:657-661). Rajak (2002:18-19) is surely incorrect in seeing Josephus's claim that the priests were the interpreters of dreams and sacred texts as a fabrication designed to appeal to his pagan audience. On Josephus as priest, see Tuval (2011:397-412; 2013:esp. 260-274).

36.War 2.159, 'There are also among them those who profess to foretell what is to come, being thoroughly trained in holy books, various purifications, and concise sayings of prophets. Rarely, if ever, do they fail in their predictions'; cf. War sayings of prophets. Rarely, if ever, do they fail in
$1.78-80 ; 2.112-113$; Ant. 13.311; 15.371-378; 17.346.

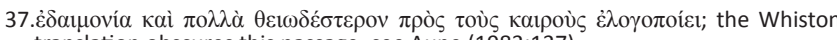
translation obscures this passage; see Aune (1983:137). 
temple of God' (War 4.388). ${ }^{38}$ Later on, he clarifies the content of this oracle and also makes reference to another (War 6.311313), ${ }^{39}$ which he links to the accession of Vespasian and may have served also as the basis for his own famous prediction (War 3.401-403). The circulation of this latter oracle receives (likely) independent confirmation in the writings of Tacitus (Hist. 5.13.2) and Suetonius (Vesp. 4.5), lending support to its historicity. ${ }^{40}$ The precise writings behind the oracle are, however, unclear - the most likely being the prophecy of Daniel (2:31-45 and/or 9:24-27). ${ }^{41}$

How these oracles became popular is unclear, but we can perhaps imagine that a priestly figure such as Josephus himself shared his charismatic exegesis of a scriptural passage with those under his influence. When the events that shortly transpired began to give credence to the veracity of the prediction, its popularity and circulation increased. In other cases, however, the use of Scripture to mediate present and future events was not as convincing. Thus a certain Jesus ben Ananias, a 'foolish peasant' ( $\tau \tilde{\omega} v$

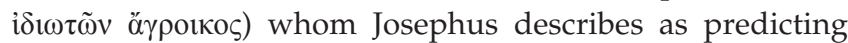
the coming destruction already 4 years prior to the outbreak of the revolt itself, was beaten severely for his message of doom, first at the command of the Jewish leaders and then of Albinus, the Roman procurator. In his mouth Josephus places reminiscences of Jeremiah's earlier prophecy (7:34; cf. $16: 9 ; 25: 10 ; 33: 11$ ) when this Jesus cries, 'A voice from the east, a voice from the west, a voice from the four winds, a voice against Jerusalem and the holy house, a voice against the bridegrooms and the brides, and a voice against this whole people!' (War 6.301).

While the historicity of such a figure is hard to determine, Josephus's own narratives provide a setting within which a Jesus ben Ananias fits. While this Jesus may have been dismissed at the time as a lunatic, he was not alone in his conviction that present and future events could be interpreted and understood through careful reading of Scripture. Perhaps the problem with a 'foolish peasant' such as Jesus ben Ananias was not that his message was not believed by the leaders, but that he broke a priestly or aristocratic monopoly on the application of scriptural prophecies and principles

38.See also War 6.109-110; Thackeray (1928:at 3.406-407, n. b.) connects this with Sib. Or. 4.115-118, but Evans (2001:377), rightly points out the chronological difficulties with this; see also idem (1992:100-101).

39.War 6.311-313, 'Thus the Jews, after the demolition of Antonia, reduced the Temple to a square, although they had it recorded in their oracles that the city lem the sanctury would be taken when the Tomplo and the sanctuary would be taken when the Temple became foursquare. But now, what did the moste whe from their country should become governor of the habitable earth. "The Jews took this prediction to belong to themselves in particular, and many of the wise men were thereby deceived in their determination. Now this oracle certainly denoted the government of Vespasian, who was appointed emperor in Judea.'

40.Regarding the possibility that Tacitus and/or Suetonius read the works of Josephus, see, for example, Schreckenberg (1997:68-70); Rajak (2002:193, n. 18)

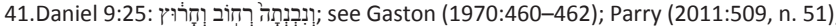
Mason (2003:49-50); Den Hollander (2014:95, n. 128). But see Tuval (2013:126), who judges all of these 'unknowable' and suggests that the ambiguity with which Josephus refers to these oracles is evidence of his lack of familiarity with the biblical text. He suggests instead that, during the writing of the War, 'Whatever he knew of the Bible is better explained as having three main sources: familiar Judea practice, local story-telling related to various geographical locations mentioned in the Bible, and above all, priestly legends witnessing to a prominent Temple bias' (128). This argument, if correct, does not detract from the extent to whic 'scriptural' material defined Josephus's view of the events of the 1st century. to contemporary events. In any case, we can recognise in summary that both before and after the destruction, Josephus and his contemporaries made sense of the tragedy by appealing to Scripture. There was true comfort to be found in the conviction that their God was at work in history for their ultimate benefit, even when the present seemed to belie their confidence in this reality. There was always hope.

\section{Jesus on the fall of Jerusalem}

The picture both pre-and-post-eventum that can be drawn from Josephus provides a valuable context within which also to analyse certain sayings of Jesus recorded in the gospels of Matthew and Luke that provide evidence of similar efforts to articulate what God was doing in AD 70. For the purposes of this article I will leave aside the question of exactly whose efforts these were - Jesus himself or the gospel writers - and will simply consider the overall themes that emerge, noting the contact points with Josephus where appropriate. I hope to demonstrate thereby that these predictions flow out of a Heilsgeschichtliche worldview similar to that of Josephus and need not be dismissed, even by those who principally reject the possibility of prophecy, as vaticinia ex eventum. In my analysis, I will focus my attention, as I did with Josephus, on those places where Jesus articulates the meaning or purpose of the destruction (Lk 19:41-44; 21:20-24; Mt 23:34-35 //Lk 11:47-51; Mt 23:37-39 // Lk 13:34-35).

The simplest explanation was for Jesus the same as we observed above for Josephus: 'simply put, Jerusalem fell for its sins' (Klawans 2010:290). But more than that can also be said. For Jesus also views the destruction as the fulfilment of previous prophecy. Thus, in the Lukan version of his wellknown discourse on the Mount of Olives, Jesus follows his prediction of the siege of Jerusalem with this assessment, 'For this is the time of punishment in fulfilment of all that has been written' (Lk 21:22). ${ }^{42}$ With the phrase 'all that has

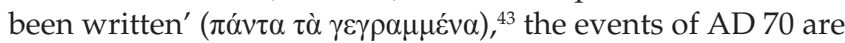
cast as the climax of scriptural prophecy and as part of the march of human history that received its shape in these same writings. Elsewhere in Luke's gospel, Jesus similarly points to his upcoming death and resurrection as the fulfilment of

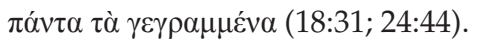

Precisely why this punishment was deserved is made clearer in the other predictions that were ascribed to Jesus. Above all, the message is that God was punishing the Jewish leaders for their rejection and violent treatment of the prophets. Thus, in a passage recorded with almost identical wording in Matthew and Luke, Jesus cries out:

Jerusalem, Jerusalem, you who kill the prophets and stone those sent to you, how often I have longed to gather your children together, as a hen gathers her chicks under her wings, and you were not willing. Look, your house is left to you desolate. (Lk 13:34-35a // Mt 23:37-39) $)^{44}$

42. For a cogent defence of the historicity of Jesus' prediction and a reasoned rejection of it as a vaticinium ex eventu, see Borg (1998:197-199); cf. Dodd (1968:69-83).

43.For this phrase, see also Josephus Ant. 11.6; 13.297; and the LXX (Jos 1:8; 9:2; 23:6 1 Chr 16:40; 2 Chr 34:21; 4 Kgdms 22:13; Jr 25:13).

44.In defence of the origin of this prophecy with Jesus, see Aune (1983:175) 
In the gospel of Matthew, this lament occurs in the context of Jesus' pronouncement of seven woes on the teachers of the law and the Pharisees. Here the charge is made even more explicit when Jesus says:

And so upon you will come all the righteous blood that has been shed on earth, from the blood of righteous Abel to the blood of Zechariah son of Berekiah, whom you murdered between the temple and the altar. Truly I tell you, all this will come on this generation. (Mt 23:35)

In the immediate context it is clear that the blood of the prophets is particularly in view (vv. 29-34), as the Lukan parallel also demonstrates (Lk 11:47-51).

This charge was not novel. Rather, its roots could be found in a scriptural pattern of history. Thus the Chronicler also linked the first fall of Jerusalem with the treatment of the prophets:

The Lord, the God of their ancestors, sent word to them through his messengers again and again, because he had pity on his people and on his dwelling place. But they mocked God's messengers, despised his words and scoffed at his prophets until the wrath of the Lord was aroused against his people and there was no remedy. (2 Chr 36:15-16; cf. 17-19)

The same explanation is given in the book of Jeremiah (Jr 7:21-35; 25:4; 29:17-19; cf. Horsley 1999:110), which held an important place not only for Josephus, but also for Matthew (Mt 2:17; 16:14; 27:9; cf. Konradt 2007:195-232, esp. 216-226). In the 1st century, even apart from its scriptural resonances, the charge may have been all the more distressing given the recent killings of such (pseudo-) prophetic figures as Theudas and the Egyptian, to whom some, at least, credited genuine prophetic abilities. ${ }^{46}$ For Jesus, however, the pronouncement seems to be intended as an inclusio, to encompass the scope of scriptural historybookended by the first death, Abel, and the last, Zechariah, ${ }^{47}$

45.I Iam grateful to Rob van Houwelingen for this reference. See also Nehemiah 9:26-27, 'But they were disobedient and rebelled against you; they turned their backs on your law. They killed your prophets, who had warned them in order to turn them back to you; they committed awful blasphemies. So you delivered them into the hands of their enemies, who oppressed them'; cf. 30-31. Scriptural examples of prophets who were killed or threatened with death are few: Elijah (1 Ki 19); Jeremiah (Jr 20:1-2; 38:6); Uriah son of Shemaiah (Jr 26:20-23); Zechariah, son of Jehoida (2 Chr 24:20-21; cf. Lk 11:50-51 // Mt 23:35). Nevertheless, colourful traditions did develop around the deaths of prophets that would have strengthened the association made in Nehemiah; see the apocryphal Lives of strengthened the association made in Nehemiah; see the apocryphal Lives of the Prophets $1.1 ; 2.1 ; 3.1-2 ; 6.2 ; 7.2$ (Isaiah, Jeremiah, Ezekiel, Micah, Amos); cf.
Evans (1992:105). Regarding the violent fate of the prophets, see also Garland (1979:179-186).

46.Josephus, Ant. 18.85-87; 20.97-98, 169-171; War 2.261-263; Acts 5:36. Josephus

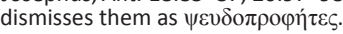

47. For this reason I agree with the judgements of the majority of interpreters who identify the prophet Zechariah son of Berekiah of Matthew 23:35 (the Lukan parallel has only Zechariah; 11:51) with the priest Zechariah son of Jehoida ( 2 Chr 24:20-21), since he stands as the last death in the Hebrew Scriptures, at least according to some renderings of the 'canon' of Jesus' day. In 2 Chronicles, he is described as having been stoned to death, which would explain further the reference in Matthew 23:37 to the stoning of God's messengers; see Evans (1992:105). For these, and other, arguments, see, for example, Davies and Allison (1992:105). For these, and other, arguments, see, for example, Davies and Allison 2004:3:318-319); Moffitt (2006:306-308); cf. Evans (2012:397). But see also Peels (2001:583-601; including $\mathrm{n} .8$ for an extensive list of scholars who agree that these texts mirror the structure and scope of the canon), who argues that the phrase is 'not temporificatory in character. Even if this is the case, however, the point remains that they stand together as representative of a long line of tragedies, in particular those found in Scripture. which is where the meaning of the coming destruction is then located. ${ }^{48}$

Closely linked to this emphasis on the killing of the prophets is the theme of innocent or righteous blood, the spilling of which is condemned throughout the Hebrew Scriptures (Gn 4:8-16; 9:5-6; Lv 17:4b; Dt 19:1-13; 21:1-9; Jr 7:6; 22:17; 26:15; J1 3:19; Lm 4:13), and connected with the outpouring of the wrath of God (Lv 18:25; Nm 35:33-34; Dt 19:4-13; 32:35, 43; Ps 79:10). Josephus also made this link, while judging those murders that occurred within the temple grounds as particularly heinous and thus especially culpable (Ant. 20.163-166; cf. War 4.150-151, 201, 215; 5.15-18, 100-105; 6.95-110). In the case of Jesus' prediction, the emphasis is not only on the death of the prophets in the distant past, including Zechariah who was killed between the temple and the altar, ${ }^{49}$ but also on the continuing and forthcoming tragedies (Peels 2001:596).

These culminate, of course, in the coming death of Jesus himself, which stands, particularly in Matthew's gospel, as the climax of the shedding of righteous blood. Matthew highlights this by employing as inter-text Lamentations 4:13, which provides the reason for the first destruction: 'But it happened because of the sins of her prophets and the iniquities of her priests, who shed within her the blood of the righteous' (cf. Moffitt 2006). Jesus is represented by Matthew as 'the righteous man' par excellence, which is developed in the narrative through the dream of Pilate's wife (27:19), Pilate's hand-washing (27:24), and the people's response (27:25). ${ }^{50}$ According to Matthew's gospel, then, Jesus' death could only result in a second temple destruction.

Luke, on the other hand, emphasises the related theme of the rejection of God's messengers, also culminating with Jesus, in keeping with Luke's emphasis on Jesus' status as prophet (4:14-21, 24-30; 7:11-17, 22; 13:33; 24:19). Thus, in his lament over Jerusalem, Jesus predicts the coming destruction in rich Old Testament language connected to the previous destruction, ${ }^{11}$ ending with this explanation, 'They will not leave one stone on another, because you did not recognise the

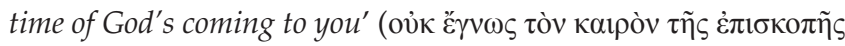
бov - Lk 19:44, my emphasis). Jesus' coming was, therefore, the ultimate visitation, which was supposed to bring peace, (see v. 41; cf. 1:79; 2:14) but instead brought judgement

48.The same message, that the coming destruction was the result of the killing of God's messengers, can be seen in some of the parables recorded in the gospels: Matthew 22:1-14; Mark 12:12. The latter is significant since Mark does not accord the same attention to Jesus' prophetic status as Luke; see Aune (1983:158).

49. Unless we accept the equation of Zechariah the son of Berekiah in Matthew 23:35 with the Zechariah son of Baruch described by Josephus as being killed in AD 69; War 4.334-343.

50.The second example (Mt 27:24) depends in part on the acceptance of a manuscript

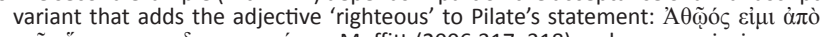

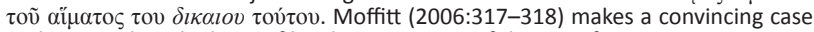
in this regard on the basis of his demonstration of the use of Lamentations $4: 13$ as an intertext throughout the gospel.

51.The Old Testament imagery and language favours its authenticity as a prediction by Jesus himself; see Dodd (1968:69-83, esp. 79); Aune (1983:191); Borg (1998: 199-203) 
because of the unbelieving response. ${ }^{52}$ These explanations of Matthew and Luke are, of course, a sharp divergence from that of Josephus. Nevertheless, they share the foundation upon which they constructed their explanations, namely that the first tragedy, as it was processed and described in Scripture, provided the key to understanding the second.

A final example of this convergence can be found in Jesus' prediction that the temple or, perhaps, Jerusalem (Gaston 1970:345-346), would be left 'deserted' or 'desolate' ('̌ $\rho \mu \circ$ ) (Lk 13:35 // Mt 23:38). ${ }^{53}$ The meaning of this prediction seems to be that the destruction would be preceded by the withdrawal of the Shekinah, the divine presence (Borg 1998:190, 196-197). Within the context of Matthew in particular this is understood as a foreshadowing of Jesus' departure from the temple and the rending of the temple veil during his crucifixion, both of which served as signposts that the temple was now forsaken. ${ }^{54}$ This was not, however, a strictly 1st century expectation. It is also the prophetic language of Ezekiel and Jeremiah. In the former book of prophecy, the condemnation of the idolaters who profaned the temple is connected directly with the departure of the glory of God $(10: 18-19 ; 11: 22)$ prior to the judgement of the city (11:7-12). In the book of Jeremiah as well, the prophet writes: 'I [God] have forsaken my house, I have abandoned my heritage, I have given the beloved of my soul into the hands of her enemies' (12:7; cf. 6:8; 22:5-9).

The divine desertion of the temple with its eventual ruin was thus rooted in the prophetic writings dealing with the first destruction and to be expected in the events leading up to the second. It is not surprising, therefore, to find this a common theme amongst Jesus' contemporaries. Josephus, as we mentioned briefly above, describes the departure of the glory of God from the temple on multiple occasions (War 2.539; 5.412; 6.299; Ant. 20.166), as does the author of 2 Baruch $(8.2 ; 64.6)$. In fact, the story circulated so widely that the Roman historian Tacitus imagined the scene vividly in his own account of the revolt. ${ }^{55}$ All agreed, then, that the God of Israel had abandoned his temple before it was consigned to flames by the Roman army.

But despite the overall doom and gloom of Jesus' messages concerning the coming destruction of the temple and the city, not all was lost. In the scriptural prophecies elements of judgement and salvation were frequently placed side by

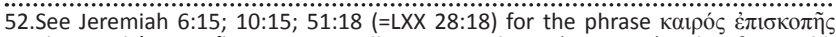

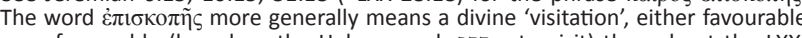
or unfavourable (based on the Hebrew verb דקפ - to visit) throughout the LXX depending on the response of the one being visited; see Gaston (1970:335-339), Borg (1998:200-201).

53.There is a manuscript problem in the Lukan passage in that some good MSS have omitted the word है $\rho \eta \mu \mathrm{o}_{\text {( }}$ (in particular Vaticanus [B]). There is, however, no substantial difference in meaning even without it. For an extensive discussion of the manuscript issues, see Theophilos (2012:38-45), who suggests that the longer reading has slightly more to commend it.

54.For Jesus as the Shekinah, see Matthew 1:23; 18:20; 28:20; cf. Davies and Allison (2004:2.789-790; 3.322-323); Moffitt (2006:306); Konradt (2007:211).

55.Hist. 5.13.1: 'Contending hosts were seen meeting in the skies, arms flashed, and suddenly the temple was illumined with fire from the clouds. Suddenly the door of the shrine opened and a superhuman voice cried: "The gods are departing" [excedere deos]: at the same moment the mighty stir of their going was heard.' side (Jr 13:15-17; 8:19ff.; 23:9ff.). Thus also Jesus, rooting the tragedy of AD 70 in salvation history, demonstrates a firm expectation of the return of divine favour, adding to his prediction of the temple's desolation, 'And I tell you, you will not see me until you say, "Blessed is he who comes in the name of the Lord"' (Lk 13:35 / / Mt 23:39). Here then he speaks of a reversal, of the return of God's presence, at such a time as repentance is shown and the final prophet, Jesus himself, accepted. Far from being a definite rejection of Israel, as many have suggested (e.g. Garland 1979:197, 203, 210-215; Newport 1995:68-76), Jesus' words presuppose that the special relationship between Israel and her God continued to determine the events of history, including future restoration (cf. Borg 1998:197; Davies \& Allison 2004:3:324-325; Moffitt 2006:320). This is consistent with the message of other early Christian texts that the church was the new Israel not by displacing the Jews, but by fulfilling the original purpose of Israel, namely to bring the Gentiles into covenant with God (Eph 2:19-22; Heb 2:16; 7:22; 8:6-13; 1 Clem. 31:2). Thus, for Jesus as for Josephus, the destruction of the temple in AD 70 was unquestionably a watershed in the Heilsgeschichte of the relationship between the God of Israel and his chosen people, but it was by no means its telos.

\section{Concluding thoughts}

The outcome of considering Jesus' predictions as they have been recorded is the recognition that the Jesus who appears in the gospels of Matthew and Luke has a consistent understanding of the coming destruction, a viewpoint that is, moreover, fully recognisable within its 1st century setting. The meaning of the events of AD 70 provided by Jesus is as Jewish as that given by the historian Josephus. And why should it not have been? Their worldviews were similarly shaped by the scriptural lenses through which they looked backwards and forwards in time. For them, history was directed by and acted upon by the God of Israel, and, therefore, the place to find answers was within Scripture, the source and deposit of his divine revelation. The suggestion, therefore, that the predictions represent the ipsissima vox of the historical Jesus - even while being tailored to suit the theological aims of the gospel writers themselves - has just as much claim to historical plausibility as the woeful cries of Jesus ben Ananias or Josephus's own interpretation of Scripture.

In addition to shedding further light on the intra-Jewish dialogue concerning the meaning of the traumatic event, the foregoing examination also prompts a legitimate historiographical question for the historian today. Is searching for the meaning of events such as the destruction of the temple in AD 70 a legitimate pursuit for historians? I submit that it is an indispensable element of doing history. Of course, much depends on one's worldview. The conviction that God is at work in the world and has been throughout history adds another dimension to the past (Deines 2013:324-326, 339). For then we stand alongside figures like Josephus and Jesus in exploring a metanarrative, in seeing events as part of the unfolding of a salvation history that is firmly embedded 
in the broader history of the world, even if the full picture will only be revealed fully in the eschaton. This approach should not be dismissed as merely a theological pursuit but, particularly within this postmodern society that prides itself on the happy coexistence of a plurality of views, ought to be recognised as a worthwhile contribution to the question of 'the meaning of history'. It simply rests on the proposition that history should be viewed veluti si Deus daretur, whereas secular scholarship takes as foundational that past events should be treated etsi Deus non daretur. ${ }^{56}$ Where both agree is that the past is worth exploring, not merely for antiquarian interests, but also for grasping more profoundly the world in which we live.

\section{Acknowledgements}

I would like to thank the Theologische Universiteit Kampen (TUK), the Netherlands, for their generosity in funding a brief post-doctoral fellowship in the Research Programme Biblical Exegesis and Systematic Theology (BEST) in the summer of 2014 for the purposes of writing this article, and to the Canadian Reformed Theological Seminary of Hamilton, Ontario, Canada, for granting me a leave of absence and making the accommodations necessary for this opportunity. I am particularly grateful for the valuable feedback and advice provided by Koert van Bekkum and Rob van Houwelingen from the TUK. In addition, I would like to thank Tessel Jonquière and Jan Willem van Henten for their willing participation in the Josephus Seminar with me and for the insights and critical reflections they offered in the discussions.

\section{Competing interests}

The author declares that he has no financial or personal relationships which may have inappropriately influenced him in writing this article.

\section{References}

Aune, D.E., 1983, Prophecy in early Christianity and the ancient Mediterranean world Eerdmans, Grand Rapids, MI.

Bilde, P., 1979, 'The causes of the Jewish War according to Josephus', Journal for the Study of Judaism 10(2), 179-202. http://dx.doi.org/10.1163/157006379 $\mathrm{X} 00048$

Bilde, P., 1988, Flavius Josephus between Jerusalem and Rome: His life, his works, and their importance, Sheffield Academic Press, Sheffield. (JSOT Press 2).

Borg, M.J., 1998, Conflict, holiness, and politics in the teachings of Jesus, Continuum, New York, MY

Cohen, S.J.D., 1982, 'Josephus, Jeremiah, and Polybius', History and Theory 21(3) 366-381. http://dx.doi.org/10.2307/2505096

Daube, D., 1980, 'Typology in Josephus', Journal of Jewish Studies 31(1), 18-36.

Davies, W.D. \& Allison, D.C. Jr., 2004, Matthew, 3 vols., Bloombury Academic, London. (International Critical Commentary).

Deines, R., 2013, Acts of God in history: Studies towards recovering a theological historiography, Christoph Ochs \& Peter Watts (eds.), Mohr Siebeck, Tübingen. (WUNT 317).

Den Hollander, W., 2014, Josephus, the emperors, and the city of Rome: From hostage to historian, Brill, Leiden. http://dx.doi.org/10.1163/9789004266834

Dodd, C.H., 1968, More New Testament studies, Manchester University Press, Manchester.

56.The latter phrase originated with Hugo Grotius (1925:13), originally published in 1625 under the title De iure belli ac pacis, who argued that politics would better be handled under the assumption that God did not exist. The former was used by be handled under the assumption that God did not exist. The former was used by
Joseph Ratzinger (Pope Benedict XVI) in a speech as cardinal at the convent of Saint Joseph Ratzinger (Pope Benedict XVI) in a speech as cardin
Scholastica in Subiaco, Italy; see Deines (2013:357-358).
Evans, C.A., 1992, 'Predictions of the destruction of the Herodian Temple in the Pseudepigrapha, Qumran, and related texts', Journal for the Study of the Pseudepigrapha, Qumran, and related texts', Journal for the Study of the
Pseudepigrapha 10, 95-154. http://dx.doi.org/10.1177/095182079200001008

Evans, C.A., 2001, Jesus and his contemporaries: Comparative studies, Brill, Leiden.

Evans, C.A., 2012, Matthew, New Cambridge Bible Commentary, Cambridge University Press, Cambridge.

Feldman, L.H., 1998, Josephus' interpretation of the Bible, University of California Press, Berkeley, CA.

Feldman, L.H., 1999, Flavius Josephus: Translation and commentary, vol. 3: Judean Antiquities, Books 1-4, ed. Steve Mason, Brill, Leiden.

Ferda, T.S., 2013, 'Jeremiah 7 and Flavius Josephus on the First Jewish War', Journal for the Study of Judaism 44, 158-173. http://dx.doi.org/10.1163/1570063112340372

Garland, D.E., 1979, The intention of Matthew 23, Brill, Leiden. http://dx.doi. org/10.1163/9789004266636

Gaston, L., 1970, No stone on another: Studies in the significance of the fall of Jerusalem in the Synoptic Gospels, Brill, Leiden. http://dx.doi.org/10.1163/9789004266001

Goodman, M., 1987, The ruling class of Judaea: The origins of the Jewish Revolt against Rome AD 66-70, Cambridge University Press, New York, NY. http://dx.doi. org/10.1017/CBO9780511552656

Goodman, M., 1994, 'Josephus as Roman citizen', in F. Parente \& J. Sievers (eds.), Josephus and the history of the Greco-Roman period, pp. 329-338, Brill, Leiden.

Goodman, M., 2007, Rome and Jerusalem: The clash of ancient civilizations, Penguin, London.

Gnuse, R.K., 1996, Dreams and dream reports in the writings of Josephus: A traditiohistorical analysis, Brill, Leiden.

Gray, R., 1993, Prophetic figures in late Second Temple Jewish Palestine: The evidence from Josephus, Oxford University Press, Oxford.

Grotius, H., 1925, The law of war and peace, transl. F.W. Kelsey, Bobbs-Merrill, Indianapolis, IN.

Halpern-Amaru, B., 1981, 'Land theology in Josephus' Jewish Antiquities', Jewish Quarterly Review 71(4), 201-229. http://dx.doi.org/10.2307/1454614

Horsley, R.A., 1999, 'Israelite traditions in Q', in R.A. Horsley \& J.A. Draper (eds.), Whoever hears you hears me: Prophets, performance and tradition in $Q$ pp. 94-122, Trinity Press International, Harrisburg, PA.

Klawans, J., 2010, 'Josephus, the rabbis, and responses to catastrophes ancient and modern', Jewish Quarterly Review 100(2), 278-309. http://dx.doi.org/10.1353/ jqr.0.0085

Klawans, J., 2012, Josephus and the ideologies of ancient Judaism, Oxford University Press, New York, NY. http://dx.doi.org/10.1093/acprof:oso/9780199928613. 001.0001

Kloppenborg, J., 2005, 'Evocatio deorum and the date of Mark', Journal of Biblical Literature 124(3), 419-450. http://dx.doi.org/10.2307/30041033

Konradt, M., 2007, 'Die Deutung der Zerstörung Jerusalems und des Tempels im Matthäusevangelium', in Christfried Böttrich \& Jens Herzer (eds.), Josephus und das Neue Testament: Wechselseitige Wahrnehmungen, pp. 195-232, Mohr und das Neue Testament: Wech
Siebeck, Tübingen. (WUNT 209).

Lim, T., 2007, 'Deuteronomy in the Judaism of the Second Temple period', in S. Moyise \& M. Menken (eds.), Deuteronomy in the New Testament, pp. 6-26, T\&T Clark, London.

Lincicum, D., 2013, Paul and the early Jewish encounter with Deuteronomy, Baker Academic, Grand Rapids, MI.

Mader, G., 2000, Josephus and the politics of historiography: Apologetic and impression management in the Bellum Judaicum, Brill, Leiden. (MS 205).

Marcus, R. (ed.), 1937, Josephus: Jewish Antiquities, Vol. IV: Books 9-11, Loeb Classical Library 326, Harvard University Press, Cambridge.

Mason, S., 1988, 'Priesthood in Josephus and the "Pharisaic Revolution"', Journal of Biblical Literature 107(4), 657-661. http://dx.doi.org/10.2307/3267627

Mason, S., 1994, 'Josephus, Daniel, and the Flavian House', in F. Parente \& J. Sievers (eds.), Josephus and the history of the Greco-Roman period, pp. 161-191, Brill, Leiden.

Mason, S., 2003, Josephus and the New Testament, 2nd edn., Hendrickson, Peabody, MA.

Mason, S., 2008, Flavius Josephus: Translation and commentary, vol. 1b: Judean War 2, ed. Steve Mason, Brill, Leiden.

McLaren, J., 1998, Turbulent times? Josephus and scholarship on Judaea in the first century CE, Sheffield Academic Press, Sheffield.

Moffitt, D.M., 2006, 'Righteous bloodshed, Matthew's passion narrative, and the Temple's destruction: Lamentations as a Matthean intertext', Journal of Biblical Literature 125(2), 299-320. http://dx.doi.org/10.2307/27638362

Newport, K.G.C., 1995, The sources and Sitz im Leben of Matthew 23, Sheffield Academic Press, Sheffield. (JSNT 117).

Nodet, E., 2007, 'Josephus' attempt to reorganize Judaism from Rome', in Zuleika Rodgers (ed.), Making history: Josephus and historical method, p. 103, Brill, Leiden. (SJSJ 110).

Parry, J.T., 2011, 'Desolation of the Temple and Messianic enthronement in Danie 11:36-12:3', Journal of the Evangelical Theological Society 54(3), 485-526.

Peels, H.G.L, 2001, "The blood "from Abel to Zechariah" (Matthew 23,35; Luke $11,50 f$.$) and the canon of the Old Testament', Zeitschrift für die alttestamentliche$ Wissenschaft 113(4), 583-601. http://dx.doi.org/10.1515/zatw.2001.016 
Price, J.J., 2005, 'Some aspects of Josephus' theological interpretation of the Jewish War', in Mauro Perani (ed.), 'The words of a wise man's mouth are gracious' (Qoh 10,12): Festschrift fur Günter Stemberger on the occasion of his $65^{\text {th }}$ birthday, $\mathrm{pp}$. 10,12): Festschrift fur Günter

Price, J.J., 2007, 'Josephus and the dialogue on the destruction of the Temple', in C. Böttrich, J. Herzer \& T. Reiprich (eds.), Josephus und das Neue Testament: Wechselseitige Wahrnehmungen. II internationales symposium zum Corpus Judaeo-Hellenisticum 25-28 Mai 2006, Greifswald, pp. 181-194, Mohr Siebeck, Tübingen. (WUNT 209).

Rajak, T., 2002, Josephus: The historian and his society, 2nd edn., Duckworth, London.

Rives, J., 2005, 'Flavian religious policy and the destruction of the Jerusalem Temple', in J. Edmondson, S. Mason \& J. Rives (eds.), Flavius Josephus and Flavian Rome, pp. 145-166, Oxford University Press, Oxford. http://dx.doi.org/10.1093/acprof:0 so/9780199262120.003.0008

Sanders, E.P., 1977, Paul and Palestinian Judaism: A comparison of patterns of religion SCM Press, London.

Schreckenberg, H., 1997, Die Flavius-Josephus-Tradition in Antike und Mittelalter, Brill, Leiden.

Spilsbury, P., 1998, 'God and Israel in Josephus: A patron-client relationship', in S Mason (ed.), Understanding Josephus: Seven perspectives, pp. 172-191, Sheffield Academic Press, Sheffield.
Spilsbury, P., 2002, 'Josephus on the burning of the Temple, the Flavian triumph and the providence of God', Society of Biblical Literature Seminar Papers 38, 306-327.

Spilsbury, P., 2003, 'Flavius Josephus on the rise and fall of the Roman Empire', Journa of Theological Studies 54(1), 1-24. http://dx.doi.org/10.1093/jts/54.1.1

Spilsbury, P. \& Begg, C., 2005, Flavius Josephus: Translation and commentary, vol. 5 Judean Antiquities, Books 8-10, ed. Steve Mason, Brill, Leiden.

Thackeray, H.St.J. (transl.), 1928, Josephus: The Jewish War, Vol. III: Books 5-7, Harvard University Press, Cambridge, MA. (Loeb Classical Library 210).

Theophilos, M.P., 2012, The abomination of desolation in Matthew 24:15, T\&T Clark International, New York, NY. (LNTS 437)

Thiselton, A.C., 2007, Hermeneutics of doctrine, Eerdmans, Grand Rapids, MI.

Tuval, M., 2011, 'A Jewish priest in Rome', in Jack Pastor, Pnina Stern \& Menahem Mor (eds.), Flavius Josephus: Interpretation and history, pp. 397-412, SJSJ 146, Brill, Leiden. http://dx.doi.org/10.1163/ej.9789004191266.i-438.164

Tuval, M., 2013, From Jerusalem priest to Roman Jew: On Josephus and the paradigms of ancient Judaism, Mohr Siebeck, Tübingen. (WUNT 2.357).

Windisch, S., 1914, Der Untergang Jerusalems (anno 70) im Urteil des Christen und Juden, S.C. van Doesburgh, Leiden. 